УДК 17.022.1(1)

Фінагіна О.В., д.е.н., професор, завідувач кафедри менеджменту та бізнесадміністрування, Черкаський державний технологічний університет

Зінченко О.А., к.е.н., доцент, доцент кафедри менеджменту та туристичного бізнесу, Дніпровський національний університет ім. Олеся Гончара

Сапельнікова Н.Л., к.е.н., професор, кафедри економіки, Київский національний університет культури та мистецтв

\title{
ПЕРЕДУМОВИ ФОРМУВАННЯ ПОЗИТИВНОГО ІМІДЖУ РЕГІОНІВ УКРАЇНИ: ПОТЕНЦАЛ, МЕХАНІЗМИ ТА ІНСТРУМЕНТИ РОЗВИТКУ СФЕРИ ПОСЛУГ
}

В статті комплексно досліджено передумови формування позитивного іміджу регіону в контексті активізації сфери послуг. Досліджено інструменти та механізми розвитку сфери послуг та її роль у формуванні потенціалу іміджу. Доведено, що лише сфера послуг має унікальні характеристики, що $є$ ключовими для оцінки в системі регіонального менеджменту. Визначено потенціал розвитку сфери послуг в Україні. Виявлено особливості сфери послуг, які сприяють формуванню позитивного потенціалу іміджу території. Виокремлено стратегічні пріоритети розвитку сфери послуг в регіонах України. Доведено універсальність політики формування позитивного іміджу для отримання результатів та ефектів в сфері індустрії послуг Проаналізовано комплекс передумов, що забезпечує залучення ефективного механізму та інструментів формування позитивного іміджу регіонів. Обгрунтовано інструментарій активізації потенціалу іміджу. Особливу роль наведено туризму як найбільш перспективної сфери щодо розвитку та поширенню іміджу регіону. У якості перспектив подальших досліджень виокремлено розробку алгоритму стратегічного управління іміджем території, дослідження синергетичного ефекту від дії всіх факторів формування іміджу. передумови

Ключові слова: сфера послуг, імідж регіону, потенціал іміджу, туризм,

Рис. 1, Літ. 9

\section{Финагина О.В., Зинченко О.А., Сапельникова Н.Л. ПРЕДПОСЫЛКИ ФОРМИРОВАНИЕ ПОЗИТИВНОГО ИМИДЖА РЕГИОНА УКРАИНЫ: ПОТЕНЦИАЛ, МЕХАНИЗМЫ И ИНСТРУМЕНТЫ РАЗВИТИЯ СФЕРЫ УСЛУГ}

В статье комплексно исследованы предпосылки формирования положительного имиджа региона в контексте активизации сферы услуг. Исследована инструменты и механизмы развития сферы услуг и ее роль в формировании потенциала имиджа. Доказано, что только сфера услуг имеет уникальные характеристики, которые являются ключевыми для оценки в системе регионального менеджмента. Определены потенциал развития сферы услуг в Украине. Выявлены особенности сферы услуг, способствующих формированию положительного потенциала имиджа территории. Выделены стратегические приоритеты развития сферы услуг в регионах Украины. Доказано универсальность политики формирования положительного имиджа для получения результатов и эффектов в сфере индустрии услуг Проанализированы комплекс предпосылок, обеспечивает привлечение эффективного механизма и инструментов формирования положительного имиджа регионов. Обоснованно инструментарий активизации потенциала имиджа. Особую роль приведены туризма как наиболее перспективной сферы по развитию и распространению имиджа региона. В качестве 
перспектив дальнейших исследований выделены разработку алгоритма стратегического управления имиджем территории, исследования синергетического эффекта от действия всех факторов формирования имиджа.

Ключевые слова: сфера услуг, имидж региона, потенциал имиджа, туризм, предпосылки

\section{Finagina O.V., Zinchenko O.A., Sapelnikova N.L. BACKGROUND FORMING POSITIVE IMAGE OF UKRAINIAN REGIONS: POTENTIAL, MECHANISMS AND TOOLS FOR SERVICES DEVELOPMENT}

The article explores the preconditions for the formation of a positive image of the region in the context of the intensification of the service sector. The article reveals the tools and mechanisms of development of the services sphere and its role in shaping the image potential. It is proved that only the service sector has unique characteristics that are key to the assessment in the regional management system. The potential of development of the sphere of services in Ukraine is determined. The article reveals features of the services sphere that contribute to the formation of the positive image of the territory potential. It identifies the strategic priorities of the services sphere development in the regions of Ukraine. It also proves the universality of the policy of forming a positive image for obtaining results and effects in the service industry. A set of prerequisites is provided, which ensures the attraction of an effective mechanism and tools for the formation of a positive image of the regions. The article substantiates the tools of activating the image potential. A particular role is given to tourism as the most promising area for the development and dissemination of the image of the region. As prospects for further research, the article distinguishes development of the algorithm of strategic management of the image of the territory, the study of the synergistic effect from the influence of all factors of image formation.

Keywords: sphere of services, image of the region, image potential, tourism, preconditions

Постановка проблеми та иї̈ зв'язок з важливими науковими чи практичними завданнями. Україна вийшла на новий шлях розвитку економіки та соціальної сфери відповідний до стандартів та векторів руху європейської спільноти. Відбуваються системні зміни в пріоритетах розвитку, нового наповнення набувають інструменти та механізми реформ, оновлення відбувається на регіональному та галузевому рівнях.

В інформаційному просторі такі зміни повинні мати повноцінне відображення у вигляді нарощення потенціалу іміджу та його системному, інформаційно ємному віддзеркалені в інформаційних ресурсах. Такі процеси не є неочікуваними, вони мають: свої історію розвитку, закономірності формування та відтворення;

особливості змін, реформування, накопичення знань та використання інформаційних ресурсів;

передумови формування та управлінського регулювання;

приклади ефективного використання;

накопичений позитивний та негативний потенціал досвіду.

В системі знань регіонального менеджменту такі процеси, явища активно накопичуються, отримують своє наукове, практичне, управлінсько орієнтоване визнання. Українські науковці все більш системно розглядають питання та проблеми формування позитивного іміджу регіонів в розрізі:

асиметрії інформаційного віддзеркалення; 

регіонів;

передумов накопиченого та ще не залученого потенціалу позитивного іміджу

унікальності досвіду в контексті практики та стратегії розвитку регіональних утворень;

теоретичного забезпечення управлінських механізмів та інструментів стратегічного та тактичного бачення позитивного іміджу;

накопичення методологічних засад та цільових методик регулювання інформаційного поля регіонів в контексті формування інвестиційної та інноваційної привабливості територій;

механізми цільового спрямування та інструменти залучення управлінського досвіду, як національного так і закордонного форматів;

управлінського аналізу та діагностування ключових проблем, що стримують якісні та кількісні зрушення в інформаційних ресурсах регіонального (національного) іміджмейкінгу;

оцінок впливу іміджу на процеси та явища економічного, соціального, культурного, інноваційного, екологічного прогресу.

Аналіз останніх досліджень і публікацій. Тема іміджмейкингу території має актуальний характері серед вітчизняних авторів. Так можна виділити таких авторів, як М.В. Макаренко [1], Т.Л. Нагорняк [2], А.Ю. Панасюк [3], О.А. Семченко [4].

В цих роботах комплексно досліджено питання формування та просування національного іміджу, розроблені загальнотеоретичні засади брендінгу територій в контексті державної інформаційної політики, обгрунтовано взаємозв'язок між іміджем держави та брендами іiі територіальних утворень, висвітлено підходи та технології формування іміджу.

Виділення невирішеної частини загальної проблеми. Незважаючи на популярність іміджевої тематики, є багато аспектів формування іміджу регіонів, які перебувають поза зоною уваги вітчизняних науковців. Серед малодосліджених аспектів іміджмейкингу територій можна виділити дослідження формування іміджу в умовах поширення сучасних трендів регіонального менеджменту.

Мета статті полягає в аналізі передумов створення іміджу території в контексті активізації механізмів та розвитку потенціалу сфери послуг.

Виклад основного матеріалу. Структура економік регіонів України має багатоступінчасту генезу, яка відображає складний історичний шлях, пройдений країною за останнє століття. Володіючи широким спектром природних ресурсів, включаючи багатий аграрний потенціал, потужним людським капіталом та, маючи перспективне геостратегічне розташування, Україна досі не змогла належно скористатися цими можливостями для досягнення збалансованого розвитку, а фрагментарність використання наявного потенціалу супроводжувалася посиленням регіональних диспропорцій. Такі характеристики економік регіонів варто визнати як невідповідні до реального економічного, технічного, природно ресурсного потенціалів, стратегічних перспектив євроінтеграції. Ділове середовище регіонів несе на собі відбиток багатьох економічних проблем та конфліктів інтересів, що формувались не одне десятиріччя. А саме, у спадок від радянського періоду Україні залишилася значна частка «традиційних» енерго- та екологоємних промислових видів діяльності із незавершеним виробничим циклом, орієнтованих на випуск переважно низькотехнологічної продукції. Орієнтованість на динамічну індустріалізацію концентрувала економічне зростання у великих містах, прискорена урбанізація гальмувала сільський розвиток. Командно- 
адміністративна економіка сформувала міцну налаштованість переважної більшості населення на соціальний патерналізм [5, с. 113].

Розвиток регіонів України на сьогодні більшість фахівців пов'язує з активним зростанням секторів аграрно-промисловий комплекс, воєнно-промисловий комплекс, ITгалузі. Така точка зору є обгрунтованою, вона позиціонує не лише майбутнє, що планується отримати в результаті впровадження державних, галузевих та регіональних програм, таким вже є сьогодення.

В світовому співтоваристві розвиток сфери послуг, іiі якість та пріоритетність в підтримці на рівні влади є визнанням економічної розвиненості, стандартом соціалізації, умовою забезпечення конкурентоспроможності територій, вектором залучення місцевих ресурсів, фактором стимулювання підприємницької активності.

Таким чином, для високорозвинених в економічному відношенні країн характерним $є$ виникнення нової технологічної парадигми та перехід домінуючої ролі в економіці до сфери послуг. Чітко прослідковуються закономірності поглиблення диференціації та посилення персоніфікації послуг, їх проникнення в індустріальну сферу, що забезпечує нову якість економічного зростання. В Україні швидка деіндустріалізація не супроводжувалась якісними змінами, що вказує на необхідність наукового обгрунтування зміни пріоритетів розвитку та запровадження ефективних механізмів державного регулювання процесів постіндустріальних трансформацій національної економіки [6, с.19]. В доповнення такої оцінки слід наголосити на різноспрямованості процесів деіндустріалізації регіонів України, новітніх форматах галузевої структури господарських комплексів та архітектури ринків (як галузевих, так i регіональних), змінах пріоритетів розвитку з позиції активної євроінтеграції.

Серед яскравих прикладів таких змін слід назвати новітній галузевий статус Львівської області та міста Львів, як центру українського туризму та IT-кластерів, Київської області як центру аграрної галузі та АПК України, Черкаської області як третього за видатками IT-центру України. Такі зміни лише набувають свого визнання, вони ще не мають стійкого характеру. Але вони принципово змінюють імідж регіонів, формують нове бачення процесів спеціалізації, кооперації, інтеграції видів діяльності, ринків, галузевих пріоритетів розвитку територій.

Серед стратегічних пріоритетів розвитку сфери послуг в Україні слід назвати такі: інтеграція сервісної діяльності 3 матеріальним виробництвом, його софтизація; виконання ролі «точок» економічного зростання територій країни, у тому числі 3 використанням кластерного підходу, що узгоджується 3 принципом поляризованого розвитку державної регіональної політики; підвищення якості та доступності соціальних послуг, тим самим поліпшення якості життя населення; формування нової світоглядної ідеології в суспільстві на засадах концепції сталого розвитку. Перспективним напрямом подальших наукових досліджень насамперед $\epsilon$ вивчення шляхів удосконалення механізмів державного управління процесами постіндустріальної трансформації національної економіки, створення адекватного інституційного середовища [6, с.23].

Пріоритетність розвитку сфери послуг, залучення іï фактично неосяжного потенціалу має свої управлінські передумови. Так лише сфера послуг має такі характеристики, що $\epsilon$ унікальними та мають ключові оцінки в системі знань менеджменту:

не потребує великого обсягу інвестицій;

покращує інвестиційний клімат територій та формує позитивні враження для іноземних інвесторів; 
має унікальний потенціал кластероутворення та інших форматів інтегрування діяльності , проектів, інвестицій, соціокультурних ініціатив;

прискорено обертає гроші, не потребує складного фінансового обслуговування;

сплачує податки в місцеві бюджети та нарощує потенціал фінансових капіталів регіонів;

підвищує якість людського капіталу, надає новітніх форматів залучення інтелектуальних продуктів, інноваційних технологій;

прискорює інформаційний прогрес та накопичує досвід активізації інформаційних ресурсів;

поліпшує якість діяльності індустріальних виробництв;

стимулюе інвестування в промисловий сектор за рахунок покращення інформаційного обслуговування;

формує платформи для прискореного просування проектів 3 кластероутворення, інтегрування та диверсифікації бізнесу;

залучає вільну робочу силу, є трудоємною;

потребує підприємницьких талантів та креативності в розвитку;

формує унікальну культуру та спрямована на мультикультурні ефекти та результати;

формує ідентичність територій на національному та субкультурному рівні;

$\epsilon$ іміджевоформуючою, оскільки саме через пряму взаємодію із споживачем впливає на суспільну думку;

зберігає та відтворює потенціали - культури, знань, суспільної взаємодії;

залучує інноваційні проекти та комерціалізує ідеї в прискореному форматі, значно швидше ніж в промисловості та на виробництвах;

інтегрує території за принципом єдності ділового середовища 3 первинним визначенням якісних параметрів оцінювання та врахування культурно-ментальних детермінант.

Україна, іï владні кола, менеджмент, бізнес вже оцінили перспективність та пріоритетність стратегічного бачення іміджу, необхідність формування цільової політики іміджмейкингу, розробку та впровадження механізмів регулювання іміджевих продуктів, включення відповідних механізмів та інструментів в стратегічні плани розвитку.

Системна впливовість позитивного іміджу України, іiі окремих територій на процеси та явища в регіональному господарському комплексі повинна формувати специфічне відношення регіональної влади до таких управлінських заходів як: аналіз, оцінка, діагностування, регулювання, корегування, планування, прогнозування залучення відповідного потенціалу. Передумовами такого складного управлінського процесу слід визнати низку змін, об'єктивного та суб’єктивного характеру (рис. 1).

Таке бачення передумов не $є$ повним, це лише ключові напрями, які вже мають системне втілення, $€$ взаємообумовленими та відповідними та прогресу знань менеджменту. Одночасно такий формат передумов надає можливості рекомендувати подальше дослідження та обгрунтування конфліктних зон та проблем управлінського характеру, що сформують цільове бачення подальшого залучення інструментарію управлінського та правого регулювання, інституційних змін. 
Напрями передумов формування ефективних механізмів

\begin{tabular}{|c|c|c|c|c|}
\hline $\begin{array}{c}\text { Процеси } \\
\text { євроінтеграції, } \\
\text { транснаціонал } \\
\text { ізації та } \\
\text { глобалізації }\end{array}$ & $\begin{array}{c}\text { Стратегічне } \\
\text { бачення } \\
\text { іміджу } \\
\text { України }\end{array}$ & $\begin{array}{c}\text { Управлінські } \\
\text { інструменти та } \\
\text { технології } \\
\text { формування та } \\
\text { корегування } \\
\text { іміджу регіонів }\end{array}$ & \begin{tabular}{|c} 
Інформатизація, \\
інтернет- \\
технології, \\
софтізація
\end{tabular} & $\begin{array}{c}\text { Системна оцінка } \\
\text { ділового середовища } \\
\text { регіонів, незалежні } \\
\text { експертизи, } \\
\text { рейтингування } \\
\text { регіонів, залучення } \\
\text { досвіду }\end{array}$ \\
\hline
\end{tabular}

Рисунок 1 - Комплекс передумов, що забезпечує залучення ефективного механізму та інструментів формування позитивного іміджу регіонів України*

*джерело: авторська розробка

I лише після методологічного наповнення та обгрунтування передумов, факторів та зон впливу, оцінки можливих управлінських конфліктів (непогодженості зон інтересів, демотиваційних впливів) рекомендуємо приступати до обгрунтування заходів:

методичних розробок та технологій управлінського аналізу;

аналізу стану іміджу в комплексному оцінюванні;

розробки основних індикаторів (показників) використання потенціалу іміджу;

моніторингу та діагностики використання потенціалу позитивного іміджу;

визначення ключових інтересів залучення механізмів активізації позитивного потенціалу імджу;

оцінки (діагностики) іміджевої привабливості території (оцінка іміджу з позиції іiі позитивності або негативності);

окреслення ризиків та конфліктів в використанні потенціалу іміджу;

обгрунтування інструментів та механізмів регуляторного впливу (корегувального впливу).

Слід позитивно оцінювати таку перспективність та векторність розвитку, але бачити майбутнє лише в таких форматах не є визнанням прогресу. В Україні є великий потенціал сфери послуг. Тут ми визнаємо наявність великої кількості можливостей, що будуть забезпечувати:

зростання національної та регіональної економіки;

формувати якісні та кількісні зміни соціальної сфери;

прискорювати темпи наукового, інноваційного, соціального та культурного прогресу.

Сфера послуг економіки України має тенденцію до зростання, яке простежується у вдосконаленні послуг, розвитку людських ресурсів, освоєнні наукового знання. Можна виділити наступні сталі риси розвитку: пожвавився розвиток наукомістких галузей сервісу, багато з яких почали спиратися на технологічно складний та інноваційний виробничий апарат. Хвиля відновлення захопила й традиційні галузі-торгівлю, транспорт, побутові послуги, рекреаційні галузі і т.п.; очікується зростання попиту на такі сфери послуг, як-роздрібний банкінг, рітейл і медицину, тобто послуги, які споживає стабільний середній клас, також можливий значний розвиток туризму - як українських курортів, таку і туроператорів, які обслуговують поїздки українців за кордон; зростають капіталовкладення до сервісного сектору України через низьку капіталомісткість і 
невисоку середню вартість інвестиційних проектів та меншу ступінь інвестиційного ризику [7, с.40].

Слід окреслити та надати наголосу на таких галузях, видах діяльності що $є$ перспективними 3 позиції залучення та системного використання позитивного потенціалу в регіонах України: туризм, ІТ-галузь, освіта, культура, охорона здоров'я.

Такі сфери та їхня діяльність унікально поєднуються в позитивному іміджі туризму, де на сьогодні отримують своє визнання і починають розвиватися нові напрями для України, які вже мають своє визнання та оцінку в світовому просторі [8]:

медичний туризм: поїздки з метою лікування як всередині країни, так і за їі межі, у випадку подорожей за кордон, отримують можливість користуватися медичними послугами інших країн, які на вдома не доступні, заборонені, коштовні або законодавчо не врегульовані;

екологічний туризм: поїздки до природних недоторканих людиною та природоохоронних територій;

волонтерський туризм: подорожі в країни, де населення потребує допомоги 3 добровільних та альтруїстських спонукань;

спортивний туризм: відвідання визначних спортивних заходів та спортивних місць (олімпійських поселень, стадіонів, спортивних музеїв тощо);

освітній туризм: поєднує відпочинок та навчання, полягає у відвідуванні занять, екскурсії з метою розширення світогляду, задоволення цікавості і досягнення інших пізнавальних цілей.

Потенціал туризму, вектори його розвитку $є$ не тільки важливою ланкою в національній економіці України, а й формують перспективи зростання на платформі стимулювання регіонів, залучення інвестицій в туристичний комплекс, створюючи позитивний імідж територій i принципово змінюючи в кращу сторону ділове середовище. Така спрямованість в розумінні перспектив майбутнього регіонів надає можливість поступального і ефективного вирішення конфліктів і проблем окремих територій в рамках стратегічного розвитку. Підмогою і управлінським інструментарієм в цьому науково-практичному процесі повинні стати:

аналіз і оцінка проблем розвитку;

управлінський аналіз потенціалу і його практичної складової для

діагностика асиметрії розвитку регіонів - інформаційної, культурної, підприємницької, інфраструктурної;

формування іміджевих індикаторів і оцінок, приведення їх до світових стандартів Тільки на основі комплексного аналізу формується науково обгрунтоване бачення проблем і зон конфліктів, визначаються головні проблеми та їх альтернативні шляхи вирішення. Ключове місце у формуванні стратегічного бачення є управлінський аналіз, його науково обгрунтовані інструменти та технології.

Також позитивний вплив від регуляторних заходів слід очікувати в комплексному прояві - зрушеннях та змінах:

балансування економічних та соціокультурних інтересів;

загальних оцінок ділового середовища;

інвестиційній та інноваційній привабливості;

Науковці наголошують, що невдало сконструйований імідж, або такий, що мимовільно виник, здатний стати основою найсильніших інформаційних збоїв в комунікаційних процесах між населенням регіону та зовнішніми спільнотами, руйнування характеристик уявної спільноти i, в кінцевому підсумку, атомізації суспільства, руйнування або дестабілізації його інституціональної структури, 
розмивання і руйнування соціальної ідентичності не тільки територіальної, а й соціальної ідентичності взагалі. Образ території зі знаком «мінус» формується внаслідок домінування аномальних природно-кліматичних або негативних політичних, соціальноекономічних чи інших явищ, що представляють будь-яку загрозу для людини, для іiі життя та діяльності, для бізнесу. Так само, наприклад, військові дії, злочинність, процвітання наркобізнесу, бідність та інші фактори стають основою негативного іміджу території. Територіям, які мають позитивний імідж, потрібен не тільки активний розвиток і просування завжди наявних позитивних аспектів образу, а й одночасна робота з реабілітації іміджу, зниження актуальності негативних характеристик [9, с.177].

Висновки та перспективи подальшого дослідження. Питання оцінювання та використання позитивного потенціалу іміджу регіонів України лише набувають актуальності. Такі питання ще зовсім недавно не мали своєї теоретичної та методологічної бази в знаннях менеджменту. Хоча 3 початку 2000-років імідж та його інформаційно-управлінське використання набуває все більшого значення в механізмах, інструментах та технологіях стратегічного розвитку регіонів не залежно від їх масштабу, підлеглості, цільового спрямування. Фахівці визнають універсальність політики формування позитивного іміджу для отримання результатів та ефектів в сфері індустрії послуг; шоу-бізнесі та регіональному менеджменті. Виняткова роль сфери послуг, яка через свої специфічні характеристики, активізує потенціал позитивного іміджу.

В якості перспектив подальших досліджень, доречним є розробка алгоритму стратегічного управління іміджем території, дослідження синергетичного ефекту від дії всіх факторів формування іміджу.

\section{СПИСОК ВИКОРИСТАНИХ ДЖЕРЕЛ}

1. Макаренко М.В. Імідж регіону як головний чинник його конкурентоспроможності / М.В. Макаренко // Актуальні проблеми економіки. - 2012. - № 2 (128). - С. 180-187

2. Нагорняк Т.Л. Брендинг території як державна та регіональна політика: моногр. / Т.Л. Нагорняк. - Донецьк: Вид-во «Ноулідж», 2013. - 367 с.

3. Панасюк А.Ю. Формирование имиджа: стратегия, психотехнологии, психотехники / А.Ю. Панасюк. - М.: Омсга-Л, 2007. - 266 с

4. Семченко О.А. Іміджева політика України: моногр. / О.А. Семченко. - К.: Знання, 2014. -272 c.

5. Сурай А.С. Проблеми та особливості формування ділового середовища регіонів україни: факторний аналіз / А.С. Сурай // Збірник наукових праць Херсонського національного технічного університету «Соціально-економічний розвиток регіонів в контексті міжнародної інтеграції». - Вип. 27(2). - Херсон: ХНТУ, 2017. - С. 112-117

6. Янковська Л.А. Стратегічні пріоритети розвитку сфери послуг України на засадах постіндустріальної економіки / Л.А. Янковська // Ефективна економіка. - 2013. - №2. - C.18-23

7. Романків І. Я. Розвиток ринку послуг в Україні / І. Я. Романків // Фінанси України. 2011. - № 11. - С. 38-45

8. Мірошник Р.О., Щир І.В. Розвиток туристичної галузі України: особливості та проблеми / Р.О Мірошник, І.В. Щир // Вісник Національного університету «Львівська політехніка». Проблеми економіки та управління. - 2013. - №754. - С.41-46

9. Зінченко О.А. Проектний підхід до створення іміджу території / О.А. Зінченко // European Journal of Management Issues. - 2017. - Вип. 25 № 3-4. - С. 176-183 